\title{
Where Did Indonesian Online Media Pioneer Stand on Internet Shutdown Issue?
}

\author{
Reza Safitri ${ }^{1)}$ Ulwan Fakhri Noviadhista ${ }^{2, a)}$ \\ ${ }^{1}$ Universitas Brawijaya, Indonesia, Malang, Indonesia \\ ${ }^{2}$ Universitas Brawijaya, Indonesia, Malang, Indonesia \\ a)author correspondence : ulwanfn@gmail.com
}

D. DOI: https://doi.org/10.18196/jkm.121030

Article Info

Article history:

Received 10 Feb 2020

Revised 26 Mar 2020

Accepted 5 May 2020

\begin{abstract}
In the past few years, the number of countries that implement internet shutdown policy has increased. The Indonesian government has also adopted a similar way. During 2019, the government has slowed or blocked internet access for three times: in May related to protest of Presidential Election in Jakarta; in August related to riots in Papua and West Papua; and in September in Wamena which also related to riots. In fact, besides its beneficial aspects, internet shutdown policy can cost bad to many sectors, including online journalism. This study tried to uncover how Detik.com - as one of the very few pioneers of online journalism in Indonesia - framed news about internet shutdown phenomena in Papua during August 2019. In this constructivist paradigm research, researchers analyzed 34 news samples using framing models from Pan and Kosicki, then discussed the findings with Social Construction of Reality Theory proposed by Berger and Luckmann. Based on the framing analysis done, Detik.com actively shaped the perception of internet shutdown as a positively aimed government's policy, although still willing to give contrary views in the imbalanced portion. It practices "crab journalism" to keep contributing to society as a media company and adapting to the political situation at the same time.
\end{abstract}

Keywords: Detik.com; Framing Analysis; Internet Shutdown; Online Journalism

\section{ABSTRAK}

Dalam beberapa tahun terakhir, negara yang menerapkan kebijakan internet shutdown jumlahnya meningkat. Pemerintah Indonesia pun menerapkan langkah serupa. Selama 2019, pemerintah telah tiga kali melakukan pelambatan atau pemblokiran akses internet, yaitu pada bulan Mei terkait protes hasil Pilpres di Jakarta; pada Agustus terkait kerusuhan di Papua dan Papua Barat; serta September di Wamena yang juga terkait kerusuhan. Padahal, di samping manfaat-manfaatnya, kebijakan internet shutdown juga berimplikasi negatif terhadap banyak sektor, termasuk jurnalisme daring. Penelitian ini mencoba mengungkap bagaimana Detik.com sebagai salah satu pionir jurnalisme daring di Indonesia melakukan framing pemberitaan fenomena internet shutdown di Papua selama Agustus 2019. Dalam penelitian berparadigma konstruktivis ini, penulis menganalisis 34 sampel berita menggunakan model framing dari Pan dan Kosicki, lalu mengaitkannya dengan Teori Konstruksi Realitas Sosial dari Berger dan Luckmann. Dari hasil analisis yang telah dilakukan, Detik.com secara aktif membentuk persepsi publik tentang internet shutdown sebagai kebijakan dari pemerintah yang bertujuan positif, sembari tetap menyediakan perspektif kontra dalam proporsi yang tak seimbang. Detik.com memainkan peran "jurnalisme kepiting" untuk tetap berkontribusi kepada masyarakat dan beradaptasi dengan situasi politik di waktu bersamaan.

Kata Kunci: Analisis Framing; Detik.com; Jurnalisme Daring; Internet Shutdown 


\section{INTRODUCTION}

During the long history of human civilization, the internet has transformed into a technology that has a central role and has changed many aspects of life nowadays. Some of these impacts enable people to communicate quickly and instantly, providing easy access to online shopping and banking, and implementing online government services to serve the public better. However, today's internet use and its future potential are questioned due to the widespread adoption of internet shutdowns by governments in many countries.

Internet shutdown can generally be understood as the termination of an internet network, mostly executed by the government. Though it is frequently appeared and heard in recent years, the intervention efforts to internet infrastructure done by the government have been occurring at least from 1995. The first intervention in 1995 turned out to be a popular policy in the millennium era and tends to increase in number. From 1995 to 2011, there were more than 600 digital network control events carried out by the government, both in authoritarian and democratic countries (Howard, et al., 2011).

Among the types of telecommunications infrastructure interventions that already existed, internet shutdown is the most extreme control of internet infrastructure. The implementation of the internet shutdown concept itself is also quite extensive, ranging from full network shutdown (total blackout), bandwidth limitation (bandwidth throttling), to blocking two-way communication platforms, including short message services, social media, or e-mail (Juniarto, 2019). However, those various motives have a similar goal: controlling online information exchange.

As a basis for understanding the concept of internet shutdown, the researcher defines internet shutdown as a disruption or termination of digital or temporary electronic communication that is intentionally carried out by the government for a particular purpose, population, or area. The various reasons regarding the context of each country are cutting hoax circulation and misinformation, battling terrorism, protecting domestic businesses from multi-national players, and anticipating threats to the state (Howard, et al., 2011; Wagner, 2018; SFLC.in, 2018; Selva, 2019; Juniarto, 2019).

On a global scale, Access Now (https://www.accessnow.org/keepiton/) - an international non-profit organization that observes internet openness - records an increase of internet shutdown phenomenon in the past three years. Throughout 2016 alone, there had been 75 internet shutdowns in various countries. That number rose to 108 a year later and 188 times in 2018 . Of the 371 documented internet shutdowns that happened from 2016 to 2018, the majority occurred in Asia (310 times). West (2016) analyzes that the impact of internet paralysis globally from July 2015 to June 2016 cost at least US\$ 2,4 billion.

Indonesia itself is not strange to internet network paralysis practice. From January to September 2019, this event has occurred three times: in May 2019 related to the protest of the 2019 Presidential Election results in Jakarta; August 2019 related to riots in Papua and West Papua, and September 2019 related to the riots in Wamena. As feared by parties such as Damar Juniarto - digital democracy practitioner and Executive Director of Southeast Asia Freedom of Expression Network (SAFEnet), the increasing frequency of internet shutdown will normalize internet shutdown practice to deal with social conflicts in Indonesia. Indonesia's vision to become a major player in the revolution industry 4.0 may also be questioned (Juniarto, 2019), not to mention other economic losses, because there are too many sectors of life that are very dependent on the internet already.

Backed by Marshall McLuhan's perspective on Technological Determinism, the digital era is considered as an accelerator to the golden age for journalism, especially from the democratization aspect (Hirst, 2011). However, the way journalism works can be disrupted when the technology, which is so relied on this practice, is suddenly paralyzed due to internet shutdown. Internet shutdown, for instance, may limit the ability of the media to provide the information needed by the public in crucial moments (De Leusse, 2017). The inability of journalists to use the internet when the network is being paralyzed can also hinder their work (Rozen, 2017).

From the perspective of the media economy, internet shutdown also disturbs the position of media companies. Take Kashmir as an example. The slowing down and even blocking of the internet network in Kashmir has impacted media weakening. The researchers also see an increasing rate of unemployment and stagnation of the economy in the country at the same time (Majeed and Gulzar, 2019). Based on those reasons, Majeed and Gulzar (2019) suggest that media entities must be advocated to remain free and independent. 
In addition, internet shutdown is also considered a threat to the freedom of the press. In democratic countries, the internet shutdown policy is closely related to the effort of social control mechanisms (Vargas-Leon, 2016). When the public cannot access information online, the government takes the initiative to provide information in order to reduce the potential of public confusion. It is feared that the one-door information during the internet shutdown from the government can violate the spirit of reform and freedom of the press that has been contained in Law No. 40 of 1999 concerning the Press. Some consider the internet shutdown as a 21 st-century repression tool (Juniarto, 2019).

From this paradox, examining the position of online media in the phenomenon of internet shutdown becomes both interesting and vital. As one of the very few pioneers of Indonesian online journalism, Detik.com is still consistent with its online platform since 1998. Citing the page from Alexa on October 10, 2019 (https://www.alexa.com/siteinfo/detik.com), on average, each visitor of the Detik.com can spend 8 minutes and 29 seconds a day on the site while the average number of pages accessed by Detik.com's visitors is 4,84 pages per day. Hence, as the native digital platform journalism, Detik.com's news production and dissemination undeniably rely much on the internet network. In this context, as one of the entities that could be disturbed by internet shutdown policy, Detik.com emerges as a suitable object for this research.

Detik.com is also a media that exists in the Indonesian media conglomeration ecosystem. In 2011, Trans Corp. (CT Corp) - a media corporation owned by businessman Chairul Tanjung acquired Detik.com (Tapsell, 2018). Now it has several sister companies, like Trans TV, Trans 7, and CNN Indonesia. Although Tanjung is not an active politician, he is close to the Indonesian government. After being appointed as Coordinating Minister for Economic Affairs (Menko Perekonomian) in Susilo Bambang Yudhoyono's presidency, Tanjung has been maintaining a close relationship with current Indonesian President Joko Widodo, from advising accompanying Widodo's family vacation in Trans Studio Cibubur - one of Tanjung's playground property ("Dipanggil Jokowi," 2014; "Ditemani CT," 2019). The close relationship between them also can be seen from the appointment of Tanjung's eldest daughter, Putri Indahsari Tanjung, as one of the presidential expert staff ("Step Aside", 2019).

Against the background described above, the researchers formulated the research problem, namely, how did Detik.com frame their reportage related to the internet shutdown phenomenon in Papua during August 2019. The researchers believe that this research will provide at least three benefits: 1) as an analysis on how internet shutdown as a public policy issue is constructed by one of Indonesian's most influential online media; 2) as an enrichment of online media studies in Indonesia; and 3) as a starting point for social researchers to examine the internet shutdown phenomenon that is on the rise and may affect various aspects of life.

\section{LITERATURE REVIEW}

In order to answer the research problem proposed, the researchers used two related theories: framing and social construction of reality theory. While the framing theory seeks to reveal certain construction on the journalism product, the social construction of reality theory supports the view that media is not a neutral entity and thus actively shaping the meaning of certain behavior and concept. The introductory of each theory that bases this research is explained below.

\section{Framing Theory}

Zhongdang Pan and Gerald Kosicki (2001) argued that society is now living the era of "talk." As communication media has been varied and overwhelming, the lines between traditional boundaries such as information and opinion, interpersonal and mass communication, or political and nonpolitical issues are blurring. Therefore, they argue that there are "talks" in the public arena that have been used or specially arranged by political elites to support their interests. This position is framed as a general concept.

Further, Pan and Kosicki (1993) put forward two interrelated conceptions of framing, namely psychological and sociological conceptions. Psychological conception emphasizes that framing focuses more on one's cognitive process in interpreting an event from a particular perspective, while the sociological conception tends to describe the social construction of reality. Although psychological and sociological conceptions are different from one another, Pan and Kosicki managed to recognize the relationship between those two conceptions and unite them into a certain model. 
In addition, Pan and Kosicki (1993) described four structural elements of the news text as a framing tool: syntactic, script, thematic, and rhetorical. The syntactic structure is related to how journalists arrange related events into the news. This element can give clues about how journalists interpret the meaning of events and where the news is heading while the script structure looks at how journalists pack a certain event. This structure can be seen by studying the $5 \mathrm{~W}+1 \mathrm{H}$ patterns in the news as well as how journalists relate a certain event to earlier ones.

Next is the thematic structure, which looks at how journalists' perspectives on facts through prepositions, sentences, or intercultural relations that form the text as a whole. Finally, the rhetorical structure related to the way journalists emphasize certain meanings. This aspect can be seen through, for example, the selection of a lexicon, picture, or photo.

According to D'Angelo and Kuypers (2010), framing research tends to reveal how news is being used by some parties, as news can be viewed as something that contains information and manipulated channel of information dissemination. A study conducted by Prastya (2016) - who has analyzed how Jawa Pos newspaper frames the Persebaya Surabaya fans chaos on September 4th, 2006 - reflects the concept of news that is being used. Through Pan and Kosicki framing analysis, Prastya (2016) found that the connection between Jawa Pos and Persebaya influenced the news frame on that issue. Jawa Pos tended to put Persebaya clean-handed and cornered Persebaya's fans with the possibility of being left by its readers so that Persebaya could still actively participate in the national soccer competition and Jawa Pos did not lose its one of the most significant news resources.

\section{Social Construction of Reality}

This theory, initially introduced by Peter Berger and Thomas Luckmann, is used to understand how human knowledge is constructed through social interaction (Littlejohn and Foss, 2011). To put it simply, the members of a community communicate with each other using language and producing social reality as a process of shared construction. Each culture or social group may develop its understanding of the world, produce its meaning about a certain behavior or abstract concept, and establish a way to understand that. That behavior or concept can then turn into a tradition that gradually is taken for granted. For communication researchers, social construction theory can lead to reflexivity and questioning taken-for-granted assumptions (Leeds-Hurwitz, 2009).

As an element of reality construction, language is a conceptualization as well as a narrative tool (Leeds-Hurwitz, 2009). In the mass media itself, language can be found in various media, including verbal (oral and written) and nonverbal (pictures, photos, tables, etc.). Therefore, language becomes an essential point in this process because, through language, social reality is constructed, and meaning is formed.

As mentioned by Yan (2019), the social construction of reality can clarify media bias. For example, media workers construct news through their subjective realities - that are in accordance with their specific selections and preferences - into objective realities that are displayed through the news organization. The news organization itself has its own political and ideological aspects. In the end, what conveyed by the media is called symbolic social reality and accepted by the viewer as an objective social reality, because the media is considered to reflect reality as it really is.

From the explanation above, it can be concluded that individuals produce the social world through words, actions, and even media products. For this reason, studying media texts is an effort to understand social reality, including concerning framing or framing events by the media.

\section{Internet Shutdown's Research Trend}

In addition, this research tried to highlight the phenomenon of internet shutdown in Indonesia that is still rarely discussed compared to a number of studies that have been conducted in other countries. Most of the previous studies on the internet shutdown that the researchers focused more on the negative aspects of this intervention to the telecommunications network. One of the studies the researchers refer to is a case study of internet shutdown in Pakistan from Wagner (2018). This study stated that the internet blocking policies - which have occurred 41 times between 2012 and 2017 have different impacts. For example, blocking the internet in a short duration is sort of a preventive step from mass mobilization. On the other hand, blocking, in the long run, is closely related to the mechanism of denying the existence of certain strata of society, which is also affiliated with authoritarian governmental practices (Wagner, 2018).

Furthermore, there is also another study from Ayalew (2019) that examined the phenomenon of internet shutdown in Ethiopia. According to Ayalew (2019), blocking the internet is a violation of the right to seek and receive information through various media and freedom of expression, which ideally 
is the core of democracy. Like in other places, when implementing the internet shutdown policy, the Ethiopian government used national security and economic growth as justifications.

Finally, the study conducted by Freyburg and Garbe (2018) tried to awake the public that internet shutdown is an undeniable threat. The decentralization of information on the internet that many believes is not technically true. The reason lies in the hierarchical dependency of internet infrastructure. In this hierarchy, individual users are currently placed under the control of the Internet Service Provider (ISP), while the ISP itself is also controlled and supervised by the more authorized party: the government.

\section{METHODS}

This study used a qualitative approach with a constructivist paradigm. The qualitative approach aims to build a preposition or explain the meaning behind reality. Specifically, on the paradigm, in line with Pan and Kosicki's approach to doing the analysis (1993), constructivism was used to see news discourse as part of the framing process.

In this study, the researchers saw Detik.com's framing on its coverage of internet shutdown in Papua during August 2019. In total, there was 34 news analyzed in this study, starting from the beginning the policy was applied on Monday, August 19, 2019, until the current Coordinating Minister for Politics and Security, Wiranto, by the time the research conducted confirmed reopening the internet network on Sunday, September 1, 2019.

To answer the problem formulation in this study, the researchers used a framing analysis method to examine the Detik.com news text about internet shutdown in Papua. Framing analysis is simply an analysis to find out how the media frame reality, including events, actors, to be presented to the public. Specifically, the framing analysis model used in this study is the model proposed by Zhongdang Pan and Gerald Kosicki.

\section{RESULT AND DISCUSSION}

After analyzing 34 news samples with Pan and Kosicki framing model, the researchers found framing patterns presented in the following structures:

\section{Syntax}

Syntactically, Detik.com framed their news about internet shutdown in Papua as an event for the sake of security. This can be seen from the usage of certain words in the title, such as "cegah" (prevent), "keamanan nasional" (national security), and "redam kerusuhan" (riot suppression). Another aspect that can be seen from the headline on Detik.com was the information that highlighted. Through this syntactic structure, Detik.com tried to emphasize that the slowing down and blocking of the internet in Papua is an effort that is not repressive and aiming at the security and stability of the country's conditions instead.

Meanwhile, seen from the samples that have been collected, Detik.com utilized news leads as the climax of events that were being reported accurately. As a result, the audience could understand the information presented in the opening paragraph only. Lead in the news samples also supported the title while maintaining specific keywords or phrases to minimize the reader's misperception. Here is one of the illustrations on how related title and lead of Detik.com news sample was:

\begin{tabular}{|c|c|}
\hline $\begin{array}{l}\text { Title } \\
\text { (translation) }\end{array}$ & $\begin{array}{l}\text { Internet di Papua Dibatasi, } \\
\text { Internet in Papua is Limited, }\end{array}$ \\
\hline Lead & $\begin{array}{l}\text { Timika - Layanan akses internet di } \\
\text { Papua dan Papua Barat masih }\end{array}$ \\
\hline (translation) & $\begin{array}{l}\frac{\text { dibatasi buntut dari demo berujung }}{\text { kerusuhan. }} \\
\text { Timika - Internet access in Papua } \\
\text { and West Papua is still limited as the } \\
\text { result of riot demonstration. } \\
\text { The first sentence of the lead }\end{array}$ \\
\hline
\end{tabular}

Kapolri: Masih Ada Penyebaran Hoax Police Chief: Hoax Still Spread The second phrase of the title Kapolri Jenderal Tito Karnavian mengatakan alasan masih berlakunya pembatasan itu lantaran masih ada oknum-oknum yang menyebarkan kabar bohong atau hoaks alias hoax.

National Police Chief Tito Karnavian explains that the limitation is still applied since there are still certain people who spread hoaxes.

The second sentence of the lead 
Detik.com also framed this Indonesian government's policy as an agreement of many parties. This could be seen from the inclusion of statements from state officials, such as President Joko Widodo; Vice President Jusuf Kalla; Minister of Communication and Information Rudiantara; National Police Chief Tito Karnavian; Presidential Chief of Staff (Kepala Staf Kepresidenan) Moeldoko; the Ministry of Communication and Information Technology (Kemkominfo) and the Indonesian National Police (Polri).

Judging from the Social Reality Construction Theory, there was a construction built collaboratively from state officials to emphasize the urgency of slowing down and blocking internet services in Papua. The narratives delivered by these figures were similar, namely internet shutdown as prevention and suppression of riots or national security. In the process, the audience's understanding of this policy could be developed and slowly accepts this policy as fairness.

\section{Script}

From the analysis of researchers, although not all news about the internet shutdown in Papua in August 2019 published by Detik.com fulfills the 5W $+1 \mathrm{H}$ element, Detik.com always tried to use these elements, so that the thematic aspects can be captured and not mislead readers. Nevertheless, as online media tend to emphasize aspects of immediacy (immediacy) in reporting and allows the publication of news that is independent (nonlinearity) (Heifetz, 2005; Foust, 2005), the information in some Detik.com news did not contain balanced sources. As a result, when reporting the government's statement about internet shutdown policy, the reader frequently did not get other alternative perspectives on the issue.

On the other hand, when Detik.com published counter-narratives such as those offered by KontraS, they also attached narratives or quotations from the government. This way of telling stories led to the conclusion that Detik.com made a framing of the news related to the issue of internet shutdown in Papua in August 2019 through the unbalanced appearance of narratives in a number of its reports.

For example, in an article on the analyzed samples contained not only President Joko Widodo's statement, but also the Minister of Communication and Information, Rudiantara, and KontraS Coordinator, Yati Andriyani. This news tried to raise the pros comment (from the Minister of Communication and Information as a government apparatus) and the cons (in terms of KontraS) regarding internet shutdown policy, as a supplement to President Jokowi's official statement, which held that government intervention in internet services was aimed at the well-being of many people.

\section{Thematic}

If viewed from a thematic point of view, the news samples in this research sample offered more than one perspective on the issue of internet shutdown in Papua in August 2019. However, the majority of news themes were indeed pro-pitched towards internet shutdown policies and voiced by high state officials or institutions related to the government. The policies implemented were also regularly reported or developed, starting from slowing down internet services, switching to blocking, to infrastructure damage, which results in telephone services being disrupted.

In addition to presenting itself as a subject in full control of the internet shutdown policy in Papua, news from the government also brought up figures claimed to have a role in the series of internet shutdown phenomena in August 2019, without mentioning or being able to mention whom the figures referred to were detailed. These figures were raised as triggers of the government's reaction to the internet shutdown policy itself. Two of them were "oknum-oknum yang menyebarkan hoaks" (agents who spread the hoax) and "terduga provokator" (suspected provocateurs).

Meanwhile, Non-Governmental Organizations (NGOs) or civil society organizations, such as KontraS and SAFEnet, launched counter-discourse and focused on highlighting the government that was deemed responsible in this policy. However, in addition to clearly highlighting the government, they also clearly referred the government to the broader concept by mentioning several related governmental institutions or government apparatus, such as "aparat keamanan" (security forces) and "Kominfo" which stood for Ministry of Communication and Information Technology.

By clearly stating the institution they consider responsible, KontraS and SAFEnet tried to offer a discourse to the readers whom they should constantly watch, as they had a certain power or authority in this issue. On the other hand, governmental parties preferred to disguise whom they tried to address 
with various considerations. Unfortunately, this discourse could lead to people suspecting each other or wrong parties that might cost a certain disadvantage in the future.

\section{Rhetorical}

From the rhetorical aspect, two things can be reviewed. First, Detik.com tended to show photos of sources or related institutions that provided the statements (newsmaker) to readers. This was vital in Detik.com's framing strategy to emphasize the credibility of the figure or institution.

Secondly, Detik.com tried to show the imbalance of the position and power of the government and civilians through the selection of vocabulary (lexicon). Some news about the internet shutdown in Papua in August 2019 on Detik.com illustrated the power of the government in this policy. The description and selection of the phrase "pemblokiran akan dicabut" (blocking will be lifted), for example, confirmed the strength of the Ministry of Communication and Information as of the party that had the authority to control telecommunications infrastructure in this country. The government also validated its policies by laying out regulations in which they have control.

Still related to the lexicon, the government statement quoted by Detik.com illustrated not only the strength but also the apological attitude. The indications were words like "hanya" (only) or "masih" (still) as in the following statements from Rudiantara: "kan itu juga tidak seluruh Papua, hanya beberapa kota tertentu..." and "jadi tidak semua ditutup, Indonesia tidak represif lah seperti negara lain. Kalau negara lain kan binary... kita masih ada voice." (This is not happening in all of Papua, only a few cities ..." and "so, not all accesses are closed, Indonesia is not as repressive as other countries. If other countries are binary ... we still have a voice.).

Meanwhile, the civic organization was narrated as a counterparty to the government with limited actions. This could be seen from the emergence of the lexicon of "protes" (protest), "somasi" (legal notice), and "desak" (urge). Finally, there was a narration from the Indonesian Ombudsman who was holding the government accountable for this policy. The lexicon used by the Ombudsman was more formal and structured, such as "evaluasi" (evaluation), "kriteria penilaian" (evaluation criteria), "transparansi" (transparency), and "akuntabilitas" (accountability).

\section{Discussion}

Based on the framing analysis that has been done, Detik.com actively shaped the perception of internet shutdown as a government policy that aimed positively, such as national security, normalization of conditions in Papua, and to reduce the circulation of hoaxes. In this framing process, Detik.com used several strategies, such as by selecting certain words, publishing incomplete reportage, involving more sources from high government officials, and reducing alternative perspectives for dialogue in some reportage.

Circulating the same narrative had also become another framing style of Detik.com's reportage. Repeating the same narratives in terms of the quantity as well as quoting sources that mostly were government officials strengthened internet shutdown framing for goodness sake. On the other hand, parties with different opinions did not have the same opportunity to express their concern, causing an imbalance proportion of narrations.

This finding could be related to the concept of a hierarchy of influence proposed by Shoemaker and Reese (1996). This concept explained that certain things influence news production in mass media, both internally and externally. While the internal factors range from an organization and newsroom policy to each journalist's preference, the external factors are closely related to the audience, advertisers, and source of the news.

Detik.com's tendency to side with the government in this issue is related to two factors. Firstly, it can be traced back to the close relationship of the media mogul Chairul Tanjung with the current Indonesian President, Joko Widodo. This factor intertwine with other factors: reaching the source of the news. As the government needed to inform publicly about its policy related to the conflict in Papua, Detik.com was there to listen. No surprise, the government could dominate the stage of event reporting at that moment, rather than civil parties in Jakarta, moreover ones in Papua.

In line with the data analysis, the researchers also obtained additional information that shows how Detik.com cooperates well with the government. This notion can be seen from the several awards that Detik.com got from the governmental institution, such as 2018 Adam Malik Award from Indonesian Ministry of Foreign Affairs, as Detik.com' contribution considered helpful in helping Indonesia's diplomacy, and foreign policy efforts and Media Online Mitra Humas Polri Terbaik Tahun 2019 
(2019 Best Online Media Partner of National Police's Public Relation), as Detik.com considered to have contributed in disseminating the performance of the police force so that public trust the National Police more (Fatmawati, 2018; Santoso, 2019).

However, as Detik.com still played their role as media that disseminate information and accommodate contrary views beyond the imbalance, Detik.com is practicing "crab journalism" (jurnalisme kepiting). Starting as Rosihan Anwar's cynicism to Kompas, it, later on, agreed and internalized by its co-founder, Jakob Oetama, as Kompas' ideology in running the media business. Oetama believed the media needs to implement "crab journalism" to keep contributing to society as a media company and adapting to the political situation at the same time. Imitating how the crab walks, media with "crab journalism" ideology will walk fast if the situation is safe and step back or wait if being threatened (Oetama, 2011). By doing this strategy, Detik.com can still stand out as mass media with a close relationship to the government and provide critics once in a while.

\section{CONCLUSION}

Yau and Al-Hawamdeh (2001) have written that although online news media have numerous advantages over news distributed on other platforms, the basic principles of good traditional journalism (accurate, neutral, and fair) should not be underestimated. If these basic principles are not met, not only will the reputation of the media itself be at stake, but also the reputation of the mass media as the information diffusion channel. Therefore, the online media companies, especially with high credibility like Detik.com, must have realized that they are risking journalism institution credibility as a whole when their products do not meet the ethics of journalism itself.

Based on the analysis conducted by the researchers, Detik.com, as one of the online media pioneer in Indonesia, tried to play safely in the internet shutdown issue during August 2019. They tended to side with the government by delivering news frames that support that policy, although still accommodating contrary views in an imbalanced portion. Looking at how Detik.com practices its journalism, the researchers conclude that Detik.com applied "crab journalism" practice. This can be seen from the ownership's relation to the political elite and the good cooperation between Detik.com and government institutions. In other words, while serving the elite's interest at the same time, the online media was still providing the information to the people. In the further potential of internet shutdown policy, this research should be material for reflection, especially if the fate of Indonesian online media, which could be threatened by wider or longer internet shutdown policy, considered.

\section{REFERENCES}

Atton, C. dan Hamilton, J. (2008). Alternative Journalism. London: SAGE Publications.

Ayalew, Y. (2019). The Internet shutdown muzzle(s) freedom of expression in Ethiopia: competing narratives. Information \& Communications Technology Law. doi: 10.1080/13600834.2019.1619906.

D’Angelo, P., \& Kuypers, J. (2010). Introduction: Doing News Framing Analysis. In D’Angelo, P., \& Kuypers, J. (Eds.). Doing News Framing Analysis Empirical and Theoretical Perspectives (pp. 1-14). New York: Routledge.

De Leusse, C. (2017, December 18). The Future of Journalism in the Internet age: Watchdogs or Lapdogs?. Ethical Journalism Network. Retrieved from https://ethicaljournalismnetwork.org/future-journalism-internet.

Dipanggil Jokowi ke Istana, CT: Bapak Presiden Konsultasi Masalah Perekonomian (2014, October 21). Detik.com. Retrieved from https://news.detik.com/berita/2725746/dipanggil-jokowi-keistana-ct-bapak-presiden-konsultasi-masalah-perekonomian?9922022=.

Ditemani CT, Jokowi Ajak Keluarga ke Trans Studio Cibubur. (2019, August 18). Detik.com. Retrieved from https://news.detik.com/berita/d-4671040/ditemani-ct-jokowi-ajak-keluargake-trans-studio-cibubur.

Fatmawati, N. I. (2018, January 8). detikcom Raih Adam Malik Award 2018. Detik.com. Retrieved from https://news.detik.com/berita/d-3805878/detikcom-raih-adam-malik-award2018?_ga=2.259751875.895759248.1572425414-596638415.1562758259. 
Foust, J. (2005). Online Journalism: Principles and Practices of News for the Web. Arizona: Holcomb Hataway Publishers.

Freyburg, T., \& Garbe, L. (2018). Blocking the Bottleneck: Internet Shutdowns and Ownership at Election Times in Sub-Saharan Africa. International Journal of Communication, 12, 38963916.

Majeed, D., \& Gulzar, Z. (2019). Economic Implications of Censorship on Media in a Conflict Zone (A Study of Media Ban and Censorship in Kashmir). International Journal of Innovative Studies in Sociology and Humanities, 4(4), 63-69.

Heifetz, T. (2005). The Multimedia Assignment Editor and Producer. In Quinn, S., \& Filak, V. (Eds.). Convergent Journalism: An Introduction: Writing and Producing Across Media (pp. 21-38). Burlington, MA: Focal Press.

Hirst, M. (2011). News 2.0: Can Journalism Survive the Internet?. Crows Nest: Allen \& Unwin.

Howard, P., Agarwal, S., \& Hussain, M. (2011). The Dictators' Digital Dilemma: When Do States Disconnect Their Digital Networks? Issues in Technology Innovation, 13. Retrieved from https://www.brookings.edu/wp-content/uploads/2016/06/10_dictators_digital_network.pdf.

Juniarto, D. (2019, September 10). Internet Shutdown di Indonesia: Ironi di Zaman Reformasi dan Revolusi $4.0 . \quad$ Kompas.com. Retrieved from https://www.kompas.com/tren/read/2019/09/10/100810565/internet-shutdown-di-indonesiaironi-di-zaman-reformasi-dan-revolusi-40?page=all.

Leeds-Hurwitz, W. (2009). Social Construction of Reality. In Littlejohn, S., \& Foss, K (Eds.). Encyclopedia of Communication Theory (pp. 891-894). Thousand Oaks: SAGE.

Littlejohn, S., \& Foss, K. (2011). Theories of Human Communication (10th ed.). Jakarta: Salemba Humanika.

Oetama, J. (2011). Dunia Usaha dan Etika Bisnis. Jakarta: Kompas.

Pan, Z., \& Kosicki, G. (1993). Framing analysis: An approach to news discourse. Political Communication, 10(1), 55-75. doi:10.1080/10584609.1993.9962963.

Pan, Z., \& Kosicki, G. (2001). Framing as a Strategic Action in Public Deliberation. In Reese, D., Gandy Jr., O., Grant, A. (Eds.). Framing Public Life Perspectives on Media and Our Understanding of the Social World (pp. 35-66). Mahwah: Lawrence Erlbaum Associates.

Prastya, N. (2016). Menolong Klub, Mengecam Suporter, Menjaga Pasar: Bingkai Berita dan Kebijakan Redaksi Desk Olahraga Jawa Pos dalam Pemberitaan Kerusuhan Bonek 4 September 2006. Komunikator, 8(2). $\quad$ Retrieved from http://journal.umy.ac.id/index.php/jkm/article/view/2232/2585.

Rozen, J. (2017, August 17). Journalists under duress: Internet shutdowns in Africa are stifling press freedom. Africa Portal. Retrieved from https://www.africaportal.org/features/journalistsunder-duress-internet-shutdowns-africa-are-stifling-press-freedom/.

Santoso, A. (2019, August 29). detikcom Raih Penghargaan Media Online Mitra Terbaik Polri. Detik.com. Retrieved from https://news.detik.com/berita/d-4685120/detikcom-raihpenghargaan-media-online-mitra-terbaik-polri.

Selva, M. (2019). Reaching for the off switch: Internet shutdowns are growing as nations seek to control public access to information. Index on Censorship, 48, 19-22. doi: 10.1177/0306422019876438.

Shoemaker, P., \& Reese, S. (1996). Mediating the Message: Theories of Influences on Mass Media Content (2nd ed.). New York: Longman.

SLFC.in. (2018). Living in Digital Darkness: A Handbook on Internet Shutdowns in India. New Delhi: SFLC.in.

Step aside, boomers: Here's Jokowi's new 'millennials' team (2019, November 22). TheJakartaPost.com. Retrieved from https:/www.thejakartapost.com/news/2019/11/22/stepaside-boomers-heres-jokowis-new-millennials-team.html.

Tapsell, R. (2018). Kuasa Media di Indonesia: Kaum Oligarki, Warga, dan Revolusi Digital (W. P. Utomo, Trans.). Tangerang Selatan: Marjin Kiri.

Vargas-Leon, P. (2016). Addressing the ultimate form of cyber security control: a multiple case study for the internet kill switch. In IConference 2016 Proceedings, Philadelphia, United States of America: University of British Columbia iSchool. doi: https://doi.org/10.9776/16565.

Wagner, B. (2018). Understanding Internet Shutdowns: A Case Study from Pakistan. International Journal of Communication, 12, 3917-3938. 
West, D. (2016). Internet shutdowns cost countries $\$ 2.4$ billion last year. Center for Technology Innovation at Brookings. Retrieved from https://www.brookings.edu/wpcontent/uploads/2016/10/intenet-shutdowns-v-3.pdf.

Yan, F. (2019). Image, Reality and Media Construction: A Frame Analysis of German Media Representations of China. Singapore: Springer.

Yau, J., \& Al-Hawamdeh, S. (2001). The Impact of the Internet on Teaching and Practicing Journalism. The Journal of Electronic Publishing, 7(1). doi: http://dx.doi.org/10.3998/3336451.0007.102. 